\title{
Characterization of Leaf Rust Resistance in Hard Red Spring Wheat Cultivars
}

\author{
L. M. Oelke and J. A. Kolmer, Department of Plant Pathology, University of Minnesota, and United States Depart- \\ ment of Agriculture-Agricultural Research Services Cereal Disease Laboratory, St. Paul MN, 55108
}

\begin{abstract}
Oelke, L. M., and Kolmer, J. A. 2004. Characterization of leaf rust resistance in hard red spring wheat cultivars. Plant Dis. 88:1127-1133.

Leaf rust, caused by Puccinia triticina Eriks., is the most common disease of wheat (Triticum aestivum L.) in the United States and worldwide. The objective of this study was to characterize seedling and adult plant leaf rust resistance in hard red spring wheat cultivars grown in Minnesota, North Dakota, and South Dakota, and postulate the identity of the seedling leaf rust resistance genes in the cultivars. Twenty-six cultivars, near-isogenic lines of Thatcher wheat that differ for single leaf rust resistance genes, and three wheat cultivars with known leaf rust resistance genes, were tested with 11 different isolates of leaf rust collected from the United States and Canada. The leaf rust infection types produced on seedling plants of the cultivars in greenhouse tests were compared with the infection types produced by the same isolates on the Thatcher near-isogenic lines to postulate which seedling leaf rust resistance genes were present. Seedling leaf rust resistance genes $L r 1, L r 2 a, L r 10, L r 16, L r 21$, and $L r 24$ were postulated to be present in spring wheat cultivars. Seedling genes $L r 3, L r 14 a$, and $L r 23$ likely were present in some cultivars but could not be clearly identified in this study. Most of the cultivars had some level of adult plant leaf rust resistance, most likely due to $\operatorname{Lr} 34$. Cultivars that had seedling resistance genes $\operatorname{Lrl}, \operatorname{Lr} 2 a, L r 10$, or $\operatorname{Lr} 16$ had poor to intermediate levels of leaf rust resistance in field plots. Cultivars with combinations of seedling resistance genes Lr16 and Lr24 with additional adult plant resistance were highly resistant to leaf rust.
\end{abstract}

Additional keywords: specific resistance

Leaf rust, caused by Puccinia triticina Eriks., is the most common disease of wheat (Triticum aestivum L.) worldwide. The most widely used and economical method for controlling leaf rust is the use of resistant cultivars. Resistance to leaf rust in wheat often is determined by adult plant resistance genes in combination with seedling resistance genes $(4,11,12)$. Many different virulence phenotypes or races of $P$. triticina are found annually in the United States (14). Wheat cultivars often are leaf rust resistant when initially released, but can be rendered susceptible due to selection and increase of virulent leaf rust races. Genes that condition effective resistance to the current leaf rust population need to be added to wheat breeding programs in order to maintain high levels of leaf rust resistance.

Genetic studies have been conducted on spring wheat cultivars to determine the number and identity of genes that condition leaf rust resistance $(3,6,13,15)$. The resistant cultivars are crossed with a sus-

Corresponding author: J. A. Kolmer

E-mail: jkolmer@umn.edu

Accepted for publication 3 June 2004.

Publication no. D-2004-0727-02R

This article is in the public domain and not copyrightable. It may be freely reprinted with customary crediting of the source. The American Phytopathological Society, 2004. ceptible parent, and $F_{3}$ or backcross $F_{2}$ families are tested with different leaf rust races to determine the number and identity of segregating resistance genes. However, genetic analysis requires time and resources to grow multiple generations of plants and test the segregating families for rust resistance.

Gene postulation of leaf rust resistance genes can be used to determine the seedling resistance genes that may be present in a large group of wheat germplasm $(27,29)$. Gene postulation uses gene-forgene specificity to hypothesize which leaf rust resistance genes may be present in the cultivars tested $(8,21)$. Resistance to wheat leaf rust can be characterized by a hypersensitive response or a chlorotic response with reduced size of uredinia. Low infection types or resistant responses occur only when a wheat line has a gene which conditions resistance to leaf rust races with the corresponding avirulence gene. Resistance genes are postulated based on the infection types of the cultivars to a series of leaf rust isolates that differ for virulence to the specific leaf rust resistance genes. Gene postulation originally was developed by Loegering et al. (16) and Browder (1). Gene postulation studies previously were conducted with hard red spring wheat cultivars that were grown in Minnesota, North Dakota, and South Dakota in the 1980s and early 1990s $(19,23,24)$.

The objective of this study was to characterize the leaf rust resistance in hard red spring wheat cultivars that have been grown in Minnesota, North Dakota, and South Dakota since 2000. The leaf rust resistance genes in these more recent cultivars have not yet been identified.

\section{MATERIALS AND METHODS}

The hard red spring wheat cultivars tested for leaf rust resistance were selected from the Minnesota Agricultural Experiment Station 2001 variety trials. The cultivars and their pedigrees, if available, are listed in Table 1. The pedigree information was collected from various sources, including research publications, the Germplasm Resource Information Network database and the United States Department of Agriculture-Cereal Disease Laboratory database. The cv. Thatcher plus 18 nearisogenic lines of Thatcher with single resistance genes (Table 2), 26 hard red spring wheat cultivars from the variety trials (Table 3), and the cvs. Era, Glenlea, and Roblin that have known seedling and adult plant $L r$ genes (Tables 1 and 3) were tested for seedling resistance.

In the seedling tests, six to eight seed of each cultivar were planted in $3.5-\mathrm{cm}^{2}$ pots in vermiculite (Sunshine Strong-Lite Medium Vermiculite Premium Grade; JR Johnson Horticultural Supplies, St. Paul, MN) in clumps spaced at the four corners of the square pot, with four cultivars per pot and six pots per tray. Seedlings were watered daily, fertilized at emergence with 20-20-20 NPK soluble fertilizer (Spectrum Group, St. Louis), and grown for 8 days in a greenhouse at temperatures of 18 to $22^{\circ} \mathrm{C}$ with $16 \mathrm{~h}$ of supplemental metal halide light. The seedlings were inoculated at 8 days after planting, at full emergence of primary leaves.

Isolates of $P$. triticina used in seedling test were collected from wheat in the United States and Canada. The isolates were selected based on either importance in leaf rust populations in the United States or for low infection types to specific $\mathrm{Lr}$ genes found in spring wheat. Isolates used for the greenhouse seedling test were THBJ 99 ND 588, TNRJ 99 VA 67-2, TLGF 00 SC 218, TDBJ 82 MN 01, SBDG 59 CAN 01, MJBJ 97 NE 406, MFBJ 94 CAN 01, MCDS 00 SD 520, MBRK 97 CAN 253-3, MBRJ 99 ND 162B, and KFBJ 97 CAN 64-1 (Table 2). The four-letter code indicated the virulence combination as designated by Long and Kolmer (17); the two-digit number indicated year of collection, followed by state abbreviation, or CAN if originally collected in Canada; and isolate number. 
The primary leaves of the seedlings were inoculated by spraying a suspension of approximately 20 to $30 \mu \mathrm{g}$ of urediniospores mixed in $350 \mu \mathrm{l}$ of Soltrol 170 oil (Phillips Petroleum Co., Borger, TX). Inoculated plants were allowed to air dry for $60 \mathrm{~min}$. The inoculated plants then were moved to a dew chamber and held at approximately $18^{\circ} \mathrm{C}$ and $100 \%$ relative humidity (RH). After $24 \mathrm{~h}$ of incubation, the plants were allowed to air dry for $60 \mathrm{~min}$. The seedling plants were fertilized with 20-20-20 NPK soluble fertilizer after the dew chamber incubation period. All plants were placed in a greenhouse at 18 to $22^{\circ} \mathrm{C}$ with $16 \mathrm{~h}$ of supplemental light and watered daily.

Seedling test infection types were evaluated at 12 days after inoculation. The in- fection types were classified using a 0-to-4 scale developed by Long and Kolmer (17), where $0=$ no hypersensitive flecks, necrosis, or uredinia; $0 ;=$ faint hypersensitive flecks; ; = distinct hypersensitive flecks; 1 $=$ small uredinia surrounded by distinct necrosis; 2 = small uredinia surrounded by distinct chlorosis; 3 = moderate size uredinia without chlorosis; 4 = very large ured-

Table 1. Pedigrees of spring wheat cultivars tested for leaf rust resistance

\begin{tabular}{|c|c|}
\hline Cultivar & Pedigree \\
\hline 2375 & Olaf // Era / Squamux 168 / Cis / ND487 // Lark \\
\hline Alsen & Grandin // Grandin / Glupro // Sumai 3 / Wheaton // Grandin / ND688 \\
\hline Amazon & Not available \\
\hline Aurora & Not available \\
\hline BacUp & Nyu-Bay // 2375 // Marshall \\
\hline Dandy & Not available \\
\hline Ember & SD3078 / Grandin \\
\hline Forge & Butte $86 / /$ Sharp/Guard \\
\hline Gunner & Not available \\
\hline Hanna & N93-2424 / AC Domain \\
\hline HJ98 & W8814 / Norak \\
\hline Ingot & Butte / SD3004 / Dalen \\
\hline Ivan & MN74103 / Success / 3 / Brule Mesa mother line // Bergen \\
\hline Keystone & Lars / Sharpshooter \\
\hline Knudson & Karl / Krona / 3 / Bergen // Erik / MN73167 \\
\hline Marshall & Waldron / Era \\
\hline McKenzie & Columbus / Amidon \\
\hline McVey & Ning 8331 / MN81136 / Vance // MN89068 \\
\hline Mercury & Not available \\
\hline Norm & MN73167 / MN81070 \\
\hline Norpro & Norseman / Pr2369 // Dalen \\
\hline Oxen & SDY366A / SDZ004A \\
\hline Parshall & Keene / ND674 \\
\hline Reeder & IAS20*4 / H567.71 // Stoa / 3 / ND674 \\
\hline Russ & SD8052 / SD2971 \\
\hline Verde & MN7663 / SBY354A \\
\hline Era & $\begin{array}{l}\text { Thatcher / Supreza // Frontana / } 3 \text { / Kenya } 58 \text { / Newthatch/7 / Frontana / 6/Frontana / Thatcher // Pembina / } 5 \text { / Frontana / } \\
\text { Thatcher / 2/Mida / Kenya 117A / 3 / Norin } 10 \text { / Brevor // unknown line / 4/Kenya } 58 \text { / Newthatch / } 2 \text { / Lee }\end{array}$ \\
\hline Glenlea & Pembina*2 / Bage // CB 100 \\
\hline Roblin & Manitou / Tobari 66 / 2 / CT615 / Neepawa \\
\hline
\end{tabular}

Table 2. Seedling infection types of Thatcher near-isogenic lines inoculated with 11 isolates of the leaf rust fungus Puccinia triticina used in this study in 2002 and $2003^{\mathrm{a}}$

\begin{tabular}{|c|c|c|c|c|c|c|c|c|c|c|c|}
\hline \multirow[b]{2}{*}{$\begin{array}{l}\text { Thatcher line, } \\
L r \text { gene }\end{array}$} & \multicolumn{11}{|c|}{ Isolates $^{\mathbf{b}}$} \\
\hline & $\begin{array}{c}\text { THBJ } 99 \\
\text { ND } 588\end{array}$ & $\begin{array}{c}\text { TNRJ } 99 \\
\text { VA 67-2 }\end{array}$ & $\begin{array}{l}\text { TLGF } 00 \\
\text { SC } 218\end{array}$ & $\begin{array}{c}\text { TDBJ } 82 \\
\text { MN } 01\end{array}$ & $\begin{array}{c}\text { SBDG } 59 \\
\text { CAN } 01\end{array}$ & $\begin{array}{c}\text { MJBJ } 97 \\
\text { NE } 406\end{array}$ & $\begin{array}{c}\text { MFBJ } 94 \\
\text { CAN } 01\end{array}$ & $\begin{array}{l}\text { MCDS 00 } \\
\text { SD 520 }\end{array}$ & $\begin{array}{l}\text { MBRK } 97 \\
\text { CAN 253-3 }\end{array}$ & $\begin{array}{l}\text { MBRJ } 99 \\
\text { ND 16-2B }\end{array}$ & $\begin{array}{c}\text { KFBJ } 97 \\
\text { CAN 64-1 }\end{array}$ \\
\hline RL 6003 Lr1 & $33^{+}$ & $33^{+}$ & $3^{+}$ & $33^{-}$ & $33^{+}$ & 3 & $33^{+}$ & $3^{+}$ & $33^{-}$ & 3 & $; 1$ \\
\hline RL 6016 Lr2a & $33^{+}$ & 3 & $33^{-}$ & $33^{-}$ & 3 & 0 & 0 & ; & 0 & ; & 3 \\
\hline RL 6047 Lr2c & $33^{+}$ & $33^{-}$ & $33^{-}$ & $33^{-}$ & $33^{-}$ & 0 & $; 1^{-}$ & ; & ; & $; 1^{-}$ & 3 \\
\hline RL 6002 Lr3 & $33^{+}$ & $33^{-}$ & $3^{+}$ & $33^{+}$ & 0 & $3^{+}$ & $3^{+}$ & 3 & $33^{+}$ & $3^{+}$ & $33^{+}$ \\
\hline RL $6010 \operatorname{Lr} 9$ & ; & $33^{+}$ & $3^{+}$ & 0 & 0 & ; & 0 & ; & ; & ; & 0 \\
\hline RL 6005 Lr16 & $33^{+}$ & $11^{+}$ & 1 & 1 & $; 1$ & 3 & $11^{-}$ & $22^{-}$ & $11^{+}$ & $22^{-}$ & $22^{-}$ \\
\hline RL 6064 Lr24 & ; & $33^{-}$ & 0 & $33^{-}$ & ; & 3 & 3 & ; & 0 & ; & $33^{+}$ \\
\hline RL 6078 Lr26 & $33^{+}$ & $11^{+}$ & $; 1^{-}$ & $; 1$ & $; 1$ & $; 1^{-}$ & $3^{+}$ & 3 & $33^{-}$ & $; 1$ & 3 \\
\hline RL 6007 Lr3ka & $22^{-}$ & $3^{+}$ & $22^{-}$ & $22^{+}$ & $22^{-}$ & $; 22^{-}$ & 2 & 2 & $3^{+}$ & $33^{+}$ & $2^{-}$ \\
\hline RL 6053 Lr11 & $22^{-}$ & $33^{+}$ & $33^{-}$ & $22^{+}$ & 2 & ;2 & $2^{+}$ & 2 & $33^{+}$ & 3 & $22^{-}$ \\
\hline RL 6008 Lr17 & $2^{+}$ & $11^{+}$ & $11^{-}$ & 2 & $33^{+}$ & $; 22^{-}$ & $2^{+}$ & 3 & $22^{-}$ & $; 1$ & $2^{-}$ \\
\hline RL 6049 Lr30 & $2^{-}$ & $33^{+}$ & $11^{-}$ & $2^{-}$ & $; 2^{-}$ & $; 22^{-}$ & 2 & 2 & $33^{-}$ & 3 & 1 \\
\hline RL $6051 \mathrm{LrB}$ & $2^{+}$ & $22^{+}$ & $22^{+}$ & $22^{+}$ & $1^{+}$ & $2^{+}$ & 2 & $3^{+}$ & $22^{+}$ & 2 & $2^{+}$ \\
\hline RL 6004 Lr10 & $3^{-}$ & $33^{+}$ & 0 & $3^{+}$ & 3 & $3^{+}$ & 3 & $3^{+}$ & 3 & 3 & $33^{+}$ \\
\hline RL 6013 Lr14a & $33^{-}$ & $3^{+}$ & $33^{+}$ & $3^{+}$ & $; 2^{-}$ & $3^{+}$ & $3^{+}$ & $3^{+}$ & $33^{+}$ & 3 & $3^{+}$ \\
\hline RL 6009 Lr18 & $; 11^{-}$ & $11^{-}$ & $33^{+}$ & $11^{-}$ & 2 & $22^{-}$ & $11^{-}$ & $; 1^{-}$ & $33^{+}$ & $; 1^{-}$ & $11^{-}$ \\
\hline RL 6012 Lr23 & $; 2^{-} 3^{+}$ & $; 2-3^{+}$ & $3^{+}$ & $3^{+}$ & ; & $; 22^{+}$ & $3^{+}$ & $; 1$ & $3^{+}$ & $2^{-} 3^{+}$ & $3^{+}$ \\
\hline RL $6058 \operatorname{Lr} 34$ & $3^{+}$ & $3^{+}$ & 3 & $33^{+}$ & $33^{+}$ & $3^{+}$ & 3 & 3 & $3^{+}$ & $33^{+}$ & $3^{+}$ \\
\hline
\end{tabular}

a Seedling infection types: $0=$ immune response, no sign of infection; ; = hypersensitive chlorotic or necrotic flecks; 1 = small uredinia surrounded by necrosis; 2 = small uredinia surrounded by chlorosis; $3=$ moderate size uredinia without necrosis or chlorosis; $4=$ large uredinia without necrosis or chlorosis; $+=$ uredinia larger than normal; $-=$ uredinia smaller than normal. A range of infection types is indicated by more than one infection type, with the predominant type listed first.

b Isolate designations: four-letter code indicates virulence combination on 16 differential lines of Thatcher wheat (17); two-digit numbers indicate year of isolate collection; followed by state of collection or CAN if isolate originated in Canada, and isolate number. 
inia without chlorosis. Designations of "+” indicated larger than normal uredinia and "-" indicated smaller than normal uredinia. All isolate-cultivar combinations were tested at least twice to confirm infection type. The infection type responses to the $P$. triticina isolates were used to determine the gene postulations of the cultivars.

Wheat cultivars were evaluated for adult plant resistance in greenhouse tests using isolates that produced high infection types on the cultivars in the seedling tests. Some cultivars were resistant to all isolates in the seedling tests. These cultivars were tested with isolates that produced intermediate or low infection types on the cultivars in the seedling tests. Twenty-six cultivars, four Thatcher near-isogenic lines (Thatcher, RL 6001 Lr12, RL 4031 Lrl3, and RL 6058 Lr34), and Era, Glenlea, and Roblin, were tested for adult plant resistance (Table 4). Four seeds of each cultivar were planted in $15-\mathrm{cm}$ pots for the adult test. The plants were watered daily, fertilized with osmocote 14-14-14, and grown under greenhouse conditions at approximately $20^{\circ} \mathrm{C}$ and $16 \mathrm{~h}$ of supplemental light. Approximately 3 to 4 weeks after planting, the plants were trimmed to three tillers. The adult plants were inoculated at the flag leaf stage at anthesis. The flag leaves were inoculated by spraying a suspension of urediniospores in Soltrol 170. Inoculated plants were allowed to air dry for $60 \mathrm{~min}$. The inoculated plants then were moved to a dew chamber and held at approximately $18^{\circ} \mathrm{C}$ and $100 \% \mathrm{RH}$. After $24 \mathrm{~h}$ of incubation, the plants were allowed to air dry again for $60 \mathrm{~min}$ and then grown for 14 days in the greenhouse at 18 to $22^{\circ} \mathrm{C}$ with $16 \mathrm{~h}$ of supplemental light.

The wheat cultivars were evaluated for field leaf rust resistance at two locations in 2002 and one location in 2003. The cultivars and Thatcher near-isogenic lines (RL 6003 Lrl, RL 6016 Lr2a, RL 6047 Lr2c, RL 6002 Lr3, RL 6005 Lr16, RL 6064 Lr24, RL 6004 Lr10, RL 6013 Lr14a, RL 6043 Lr21, RL6012 Lr23, Thatcher, RL $6001 \mathrm{Lrl2}$, RL $4031 \mathrm{Lrl3}$, and RL 6058 Lr34, RL 6122-2 Lrl and Lr13, RL 6108-1 Lr1 and Lr34, RL 6109-1 Lr2a and Lr34, RL 6110-1 Lr3 and Lr34, RL 6114 Lr13 and $L r 34$, RL 6128-1 Lr16 and Lr13, RL 6115-1 Lr16 and Lr34, RL 6131-1 Lr21 and Lr13, RL 6118-2 Lr21 and Lr34, and RL 6132 Lr24 and Lr13) were assessed for field leaf rust resistance (Table 5). The cultivars and near-isogenic lines were planted in field plots at St. Paul, MN and
Fargo, ND in late April 2002. In 2003, the St. Paul field was planted in mid-April. Each cultivar and near-isogenic line was planted in approximately $3-\mathrm{m}$ rows, $30 \mathrm{~cm}$ apart, and 40 to 50 seed were planted per plot. Spreader rows of the susceptible cv. Max were planted perpendicular at the St. Paul plots and were inoculated in early June with isolates THBJ 99 ND 588, MCDS 00 SD 520, and MBRJ 99 ND 162B. The isolates were chosen because THBJ and MCDS are prevalent in the current rust population and MBRJ was common in the mid-1990s. For the St. Paul field inoculations, a mixture of the three isolates in Soltrol 170 oil was sprayed on the spreader rows in early to mid-June using a backpack sprayer. The Fargo plots were infected with the naturally occurring leaf rust population.

The severity and response rating for the adult plant field resistance was based on the modified Cobb scale (22). The host infection response was rated as $\mathrm{R}=$ resistant, very small uredinia with necrosis; MR $=$ moderately resistant, small to moderate uredinia with necrosis; MS = moderately susceptible, small to moderate uredinia with chlorosis; and $\mathrm{S}=$ susceptible, large uredinia without necrosis or chlorosis. The

Table 3. Seedling infection types of hard red spring wheat cultivars with 11 isolates of the leaf rust fungus Puccinia triticina used in this study in 2002 and $2003^{\mathrm{a}}$

\begin{tabular}{|c|c|c|c|c|c|c|c|c|c|c|c|c|}
\hline \multirow[b]{2}{*}{ Cultivar } & \multirow[b]{2}{*}{$\begin{array}{c}L r \text { genes } \\
\text { postulated }\end{array}$} & \multicolumn{11}{|c|}{ Isolates $^{b}$} \\
\hline & & $\begin{array}{l}\text { THBJ 99 } \\
\text { ND } 588\end{array}$ & $\begin{array}{c}\text { TNRJ } 99 \\
\text { VA 67-2 }\end{array}$ & $\begin{array}{c}\text { TLGF 00 } \\
\text { SC } 218\end{array}$ & $\begin{array}{c}\text { TDBJ 82 } \\
\text { MN 01 }\end{array}$ & $\begin{array}{c}\text { SBDG } 59 \\
\text { CAN } 01\end{array}$ & $\begin{array}{c}\text { MJBJ } 97 \\
\text { NE } 406\end{array}$ & $\begin{array}{c}\text { MFBJ } 94 \\
\text { CAN } 01\end{array}$ & $\begin{array}{c}\text { MCDS 00 } \\
\text { SD 520 }\end{array}$ & $\begin{array}{l}\text { MBRK 97 } \\
\text { CAN 253-3 }\end{array}$ & $\begin{array}{l}\text { MBRJ 99 } \\
\text { ND 16-2B }\end{array}$ & $\begin{array}{c}\text { KFBJ } 97 \\
\text { CAN 64-1 }\end{array}$ \\
\hline 2375 & $L r l^{\mathrm{c}}$ & 3 & 2 & $33^{-}$ & 2 & 0 & $2+3$ & $22^{+}$ & $33^{+}$ & $; 2$ & 3 & ; \\
\hline Alsen & $\operatorname{Lr} 2 a, \operatorname{Lr} 10$ & $3^{+}$ & $33 \% ; 1$ & $; 1$ & $33^{-1} / 2^{-}$ & $; 1^{-}$ & 0 & 0 & 0 & 0 & ; & 3 \\
\hline Amazon & Lr1, Lr10 & $3^{+}$ & $3^{+}$ & $; 1^{-}$ & $3^{+}$ & $3^{+}$ & $33^{+}$ & $33^{+}$ & $2^{-}$ & $3^{+}$ & $3^{+}$ & ;1 \\
\hline Aurora & Lr16 & 3 & $; 1$ & ; & $1^{+}$ & $; 1^{-}$ & $33^{+}$ & $; 1^{-}$ & $; 1$ & $2^{-}$ & $22^{-}$ & $; 1^{-}$ \\
\hline BacUp & Lrl, Lrlo & $3^{+}$ & $3^{+}$ & ; & $33^{+}$ & $3^{+}$ & $33^{+}$ & 3 & $3^{+}$ & $3^{+}$ & $3^{+}$ & 0 \\
\hline Dandy & Lr24 & ; & 23 & ; & 3 & 0 & $22^{-}$ & $11^{-}$ & 0 & 0 & ; & $22^{-}$ \\
\hline Ember & Lr2a, Lr16 & $33^{+}$ & $; 1$ & ; & $11^{+}$ & $; 1$ & $; 1$ & $1^{-}$ & $; 1$ & $22^{-}$ & $; 1$ & $11^{-}$ \\
\hline Forge & $\operatorname{Lr} 2 a, \operatorname{Lr} 16$ & $2+3$ & $; 1$ & $; 1^{-}$ & 1 & $; 1^{-}$ & 0 & $; 1^{-}$ & $; 1^{-}$ & $11^{-}$ & $; 1$ & $11^{-}$ \\
\hline Gunner & $\operatorname{Lr} 2 a^{\mathrm{c}}$ & 3 & $3^{+}$ & 3 & $33^{+}$ & $; 1^{-}$ & ; & 0 & 0 & 0 & ; & $2^{+} 3$ \\
\hline Hanna & Lr16 & 2 & 2 & 0 & 1 & 0 & $; 2^{-}$ & $; 1$ & $; 1^{-}$ & $1^{+}$ & 2 & $; 1^{-}$ \\
\hline HJ98 & $\operatorname{Lr} 10^{\mathrm{c}}$ & 3 & $3^{+}$ & $; 1$ & 3 & $; 1^{-}$ & $3^{+}$ & $3^{+}$ & ; & $3^{+}$ & $3^{+}$ & $3^{+}$ \\
\hline Ingot & Lr16 & $3^{+}$ & $; 1$ & 0 & $1^{+}$ & $; 1$ & $2^{+} 3$ & 0 & $; 1^{-}$ & $1^{+}$ & $; 1$ & $11^{-}$ \\
\hline Ivan & Lr24 & $; 1^{-}$ & 2 & 0 & $22^{+}$ & ; & $; 2^{+}$ & $11^{+}$ & ; & 0 & ; & $1^{+}$ \\
\hline Keystone & Lr16 & 23 & $; 1$ & 0 & $11^{+}$ & 0 & $; 2^{+}$ & $1^{-}$ & $; 1$ & $1^{+}$ & $; 1$ & 0 \\
\hline Knudson & Lr16 & 2 & $; 1^{-}$ & 0 & $11^{+}$ & 0 & $; 2^{-}$ & 0 & $; 1^{-}$ & ;1 & $; 1^{-}$ & 1 \\
\hline Marshall & $\operatorname{Lr} 2 a, \operatorname{Lr} 10^{\mathrm{c}}$ & $3^{+}$ & $3^{+}$ & 0 & $33^{+}$ & $; 1^{-}$ & ; & 0 & ; & ; & ; & 3 \\
\hline McKenzie & $\operatorname{Lr} 21$ & ; & 0 & $;$ & $;$ & $; 1^{-}$ & ; & 0 & ; & 0 & ; & ; \\
\hline McVey & Lr16 & $33^{+}$ & $; 2$ & $; 1$ & $11^{+}$ & ;1 & $33^{+}$ & $; 1$ & $22^{+}$ & 2 & $22^{+}$ & $11^{-}$ \\
\hline Mercury & Lr16 & $22^{+}$ & $; 1$ & 0 & 1 & $; 1^{-}$ & $33^{+}$ & $; 1^{-}$ & $; 1^{-}$ & ; & $; 1^{-}$ & $; 1^{-}$ \\
\hline Norm & Lr16 & $2^{+} 3$ & $; 1^{-}$ & 0 & $1^{+}$ & 0 & $; 1^{-}$ & $; 1^{-}$ & $; 1$ & $; 1$ & $; 1$ & $; 1^{-}$ \\
\hline NorPro & $\operatorname{Lr} 2 a, \operatorname{Lr} 16$ & $3^{+}$ & $; 1$ & 0 & 1 & ; & ; & 0 & ; & 0 & 0 & 0 \\
\hline Oxen & $\operatorname{Lr} 1, \operatorname{Lr} 2 a, \operatorname{Lr} 10^{\mathrm{c}}$ & $3^{+}$ & $3^{+}$ & $; 1^{+}$ & $33^{+}$ & $1^{-}$ & ; & 0 & ; & ; & ; & 0 \\
\hline Parshall & Lr16 & $3^{+}$ & $1^{-}$ & $; 2^{-}$ & $11^{-}$ & 0 & ;2 & $; 1$ & $; 1^{-}$ & $11^{+}$ & $; 1$ & $11^{-}$ \\
\hline Reeder & $\operatorname{Lr} 2 a, \operatorname{Lr} 16$ & $3^{+}$ & $; 1$ & ; & $11^{+}$ & 0 & ; & 0 & ; & ; & ; & $11^{+}$ \\
\hline Russ & $\operatorname{Lr} 2 a, \operatorname{Lr} 10^{\mathrm{c}}$ & 3 & 3 & 0 & $33^{-}$ & 0 & ; & 0 & 0 & 0 & ; & ;2 \\
\hline Verde & Lr16 & $3^{+}$ & 0 & $;$ & 0 & 0 & $; 2+3$ & 0 & $; 1$ & $; 1^{-}$ & $; 1$ & 0 \\
\hline Era & $\operatorname{Lr} 10$ & $3^{+}$ & $3^{+}$ & 0 & $33^{+}$ & $33^{+}$ & $3^{+}$ & $3 / ; 2$ & $3^{+}$ & $3^{+}$ & $3^{+}$ & $33^{+}$ \\
\hline Glenlea & Lrl & $3^{+}$ & $3^{+}$ & $; 22^{+}$ & $33^{+}$ & $3^{+}$ & $3^{+}$ & $3^{+}$ & $; 1$ & $3^{+}$ & ; & 0 \\
\hline Roblin & $\operatorname{Lr} 1, \operatorname{Lr} 10$ & $3^{+}$ & $3^{+}$ & 0 & $33^{+}$ & $3^{+}$ & $33^{+}$ & $33^{+}$ & 3 & $3^{+}$ & $3^{+}$ & ; \\
\hline
\end{tabular}

a Seedling infection types: $0=$ immune response, no sign of infection; ; = hypersensitive chlorotic or necrotic flecks; $1=$ small uredinia surrounded by necrosis; 2 = small uredinia surrounded by chlorosis; $3=$ moderate size uredinia without necrosis or chlorosis; $4=$ large uredinia without necrosis or chlorosis; + = uredinia larger than normal; $-=$ uredinia smaller than normal. A range of infection types is indicated by more than one infection type, with the predominant type listed first.

b Isolate designations: four-letter code indicates virulence combination on 16 differential lines of Thatcher wheat (17); two-digit numbers indicate year of isolate collection; followed by state of collection or CAN if isolate originated in Canada, and isolate number.

c An additional gene, either $L r 3, L r 14 a$, or $\operatorname{Lr} 23$. 
St. Paul plots were scored in mid-July 2002 and 2003, and the Fargo plot was scored in late July 2002. Leaf rust severity and resistance responses were recorded when the susceptible cv. Thatcher had leaf rust severity of at least $80 \%$ in mid-July.

\section{RESULTS}

Seedling resistance. The infection types of the $11 P$. triticina isolates to 18 Thatcher near-isogenic lines are listed in Table 2, for comparison with the cultivar infection types in Table 3 . The Thatcher line with Lr23 varied for low and high infection type to isolates THBJ, TNRJ, and MBRJ. This gene previously has been noted to be very temperature sensitive $(2,18)$. The seedling infection types of the $P$. triticina isolates to the hard red spring wheat cultivars are listed in Table 3 . The infection types of the cultivars and the Thatcher near-isogenic lines to the different $P$. triticina isolates determined the gene postulations. For example, Gunner had low infection type of 0 ; to $; 1^{-}$to isolates MJBJ, MFBJ, MCDS, MBRJ, and MBRK, which are all avirulent to $L r 2 a$ (Table 2). Gunner had high infec-

Table 4. Adult plant infection types of hard red spring wheat cultivars to isolates of the leaf rust fungus Puccinia triticina

\begin{tabular}{|c|c|c|c|c|c|}
\hline Cultivars & Postulated $L r$ genes & Isolate $^{\mathrm{a}}$ & $\begin{array}{c}\text { Infection } \\
\text { type }^{b}\end{array}$ & Isolate $^{\mathbf{a}}$ & $\begin{array}{c}\text { Infection } \\
\text { type }^{\mathrm{b}}\end{array}$ \\
\hline 2375 & Lrl & THBJ & ;23 vf & MCDS & $; 23 \mathrm{f}$ \\
\hline Alsen & Lr2a, Lr10 & THBJ & $; 23$ vf & TNRJ & 0 \\
\hline Amazon & Lrl, $\operatorname{Lr} 10$ & THBJ & $23^{+}$ & TNRJ & $; 23 \mathrm{vf}$ \\
\hline Aurora & Lr16 & THBJ & $23^{+}$ & MBRJ & $; 1^{-}$ \\
\hline BacUp & Lrl, Lr10 & THBJ & $; 23 \mathrm{f}$ & MCDS & $; 23 \mathrm{f}$ \\
\hline Dandy & $\operatorname{Lr} 24$ & TDBJ & $; 12^{-}$ & TNRJ & ; \\
\hline Ember & $\operatorname{Lr} 2 a, \operatorname{Lr} 16$ & THBJ & $; 12^{-}$ & MBRK & $; 2^{-}$vf \\
\hline Forge & Lr2a, Lr16 & THBJ & $; 12^{-}$ & MCDS & $; 2$ \\
\hline Gunner & $\operatorname{Lr} 2 a$ & THBJ & $; 2$ & TNRJ & $;$ \\
\hline Hanna & $\operatorname{Lr} 16$ & THBJ & $; 2^{-}$vf & MCDS & $; 2^{-}$vf \\
\hline HJ98 & Lr10 & THBJ & $23^{+}$ & MBRJ & $; 2 \mathrm{vf}$ \\
\hline Ingot & Lrl6 & THBJ & $23^{+}$ & MBRK & $;$ \\
\hline Ivan & $\operatorname{Lr} 24$ & TDBJ & $; 1$ & TNRJ & ; \\
\hline Keystone & Lrl6 & THBJ & $23 \mathrm{f}$ & MCDS & $2^{-} 3^{-} \mathrm{vf}$ \\
\hline Knudson & Lr16 & THBJ & 0 & TDBJ & 0 \\
\hline Marshall & $\operatorname{Lr} 2 a, \operatorname{Lr} 10$ & THBJ & $23^{+}$ & TNRJ & $23^{+}$ \\
\hline McKenzie & $\operatorname{Lr} 21$ & THBJ & 0 & MCDS & $; 2 \mathrm{f}$ \\
\hline McVey & Lr16 & THBJ & $; 23 \mathrm{f}$ & MCDS & $; 23 \mathrm{vf}$ \\
\hline Mercury & $\operatorname{Lr} 16$ & THBJ & $23 \mathrm{f}$ & MCDS & 0 \\
\hline Norm & Lr16 & THBJ & $; 1$ & MCDS & $; 2^{-}$vf \\
\hline Norpro & $\operatorname{Lr} 2 a, \operatorname{Lr} 16$ & THBJ & $; 2^{-}$vf & MCDS & $; 2^{-} \mathrm{vf}$ \\
\hline Oxen & $\operatorname{Lr} 1, \operatorname{Lr} 2 a, \operatorname{Lr} 10$ & THBJ & $; 23 \mathrm{f}$ & TNRJ & ; \\
\hline Parshall & Lr16 & THBJ & $; 2 \mathrm{vf}$ & MCDS & 0 \\
\hline Reeder & $\operatorname{Lr} 2 a, \operatorname{Lr} 16$ & THBJ & $23 \mathrm{f}$ & MCDS & 0 \\
\hline Russ & $\operatorname{Lr} 2 a, \operatorname{Lr} 10$ & THBJ & 0 & TDBJ & 0 \\
\hline Verde & Lr16 & THBJ & 0 & MCDS & $; 1^{-} \mathrm{vf}$ \\
\hline Era & Lr1, Lr13, Lr34 & THBJ & 23 & MCDS & $23 \mathrm{f}$ \\
\hline Glenlea & Lr1, Lr34 & THBJ & $; 23 \mathrm{f}$ & MCDS & ;3 vf \\
\hline Roblin & $\operatorname{Lr} 1, \operatorname{Lr} 10, \operatorname{Lr} 13, \operatorname{Lr} 34$ & THBJ & $; 23 \mathrm{f}$ & MCDS & $23 \mathrm{f}$ \\
\hline Thatcher & ... & THBJ & $3^{+}$ & MCDS & $3^{+}$ \\
\hline RL 6001 & $\operatorname{Lr} 12$ & THBJ & $3^{+}$ & MCDS & $3^{+}$ \\
\hline RL 4031 & $\operatorname{Lrl3}$ & THBJ & $3^{+}$ & MCDS & $3^{+}$ \\
\hline RL 6058 & Lr34 & THBJ & $23 \mathrm{f}$ & MCDS & $23 \mathrm{f}$ \\
\hline
\end{tabular}

${ }^{a}$ Isolate designations: four-letter code indicates virulence combination on 16 differential lines of Thatcher wheat (17).

${ }^{\mathrm{b}}$ Seedling infection types: $0=$ immune response, no sign of infection; ; = hypersensitive chlorotic or necrotic flecks; 1 = small uredinia surrounded by necrosis; $2=$ small uredinia surrounded by chlorosis; 3 = moderate size uredinia without necrosis or chlorosis; $4=$ large uredinia without necrosis or chlorosis; $+=$ uredinia larger than normal; $-=$ uredinia smaller than normal. A range of infection types is indicated by more than one infection type, with the predominant type listed first; $f=$ fewer pustules and $\mathrm{vf}=$ very few pustules. types of ;2 to $22^{+}$to isolates TNRJ, TDBJ, MBRK, and MFBJ. Alsen, Marshall, and Russ were postulated to have $L r 2 a$ and Lr10, because all had low infection types to isolates avirulent to $\operatorname{Lr} 2 a$ and had a low infection type to isolate TLGF, which is avirulent to Lr10 (Table 2). Alsen and Marshall had low infection types to SBDG, which indicated that both also could have either $L r 3, L r 14$, or $L r 23$. Alsen was heterogeneous for low and high infection type to isolates TNRJ and TDBJ, which indicated that Alsen was a mixture that varied for an additional resistance gene. Russ had a low infection type of ;2 to KFBJ, which was too high to be conditioned by $\mathrm{Lrl}$ (Table 2). An additional resistance gene may be in Russ. Amazon, BacUp, and Roblin were postulated to have Lrl and Lr10, because all had low infection types to isolates KFBJ and TLGF. Amazon also had low infection type of $2^{-}$to isolate MCDS, which indicated that this cultivar may have an additional resistance gene or genes. Glenlea had an infection type of 0 ; to KFBJ, which indicated that $L r 1$ was present. An additional resistance gene must be present because isolates TLGF, MCDS, and MBRJ, had low infection types of ; to $; 22^{+}$to Glenlea. Dandy had infection types of $22^{-}$to 3 to isolates TNRJ, TDBJ, MJBJ, and KFBJ, which are all virulent to $L r 24$ (Table 2). Dandy had very low infection types to all other isolates; therefore, it was postulated to have $\operatorname{Lr} 24$. The cultivar Ivan had infection types of $; 2^{+}, 2$, and $22^{+}$to isolates MJBJ, TNRJ, and TDBJ, which are all virulent to $L r 24$ (Table 2). Ivan was postulated to have $\operatorname{Lr} 24$ and likely has an additional gene.

HJ98 and Era were postulated to have Lrl0, because both had a low infection type to TLGF. HJ98 also had a low infection type to isolate SBDG, which indicated that either $L r 3, L r 14 a$, or $L r 23$ was present. The low infection type of ; (fleck) to isolate MCDS indicated that HJ98 had an additional resistance gene. Era was heterogeneous for high and low infection types to isolate MFBJ. Oxen was postulated to have $L r l, L r 2 a$, and $L r 10$ because it had low infection types to all isolates avirulent to $L r 2 a$, and had low infection types to KFBJ and TLGF. Oxen also had a low infection type to SBDG, which indicated that either Lr3, Lr14a, or Lr23 was present.

Cvs. Aurora, Hanna, Ingot, Keystone, Knudson, McVey, Mercury, Parshall, and Verde had infection types of 2 to $3^{+}$to isolates THBJ and MJBJ and low infection types of ; to ;1 to all other isolates (Table 3 ). THBJ and MJBJ were the only isolates virulent to Lrl6 used in this study (Table 2 ); therefore, the infection types indicated that these cultivars have Lrl6. Norm had an infection type of $2^{+} 3$ to THBJ and $; 1^{-}$to MJBJ, which indicated that Norm has Lr16 plus another resistance gene. Cvs. Ember, Forge, Norpro, and Reeder had infection types of $2^{+} 3$ to $3^{+}$to isolate THBJ only, 
which indicated that genes $\operatorname{Lr} 2 a$ and LrI6 were present. Isolate MJBJ had low infection types to Ember, Forge, Norpro, and Reeder because it is avirulent to $\operatorname{Lr} 2 a$ (Table 2).

McKenzie had a low infection of 0 ; to $; 1^{-}$to all isolates. All of the isolates had a low infection to RL 6043 Lr21 (data not shown), a parent of Amidon, which in turn is a parent of McKenzie. McKenzie likely has $\operatorname{Lr} 21$.

Adult plant and field resistance. All cultivars except Dandy and Ivan were tested for adult plant infection type with isolate THBJ and a second isolate that varied for different cultivars (Table 4). THBJ had an infection type of $3^{+}$with many uredinia on adult plants of the susceptible control Thatcher, and also to the Thatcher lines with the adult plant resistance genes $\operatorname{Lr} 12$ and LrI3. THBJ had an infection type of 23 , with fewer uredinia on the Thatcher line with the adult plant resistance gene $L r 34$. None of the cultivars had as high an infection type as Thatcher to isolate THBJ. Cvs. McKenzie, Knudson, Norm, Russ, and Verde had very low infection types of 0 ; to ; 1 to THBJ. Cvs. Ember, Forge, Gunner, Hanna, Norpro, and Parshall had low infection types of $; 12^{-}$to $; 2$. Cvs. Reeder, McVey, Oxen, 2375, Alsen, BacUp, and Glenlea had an infection type of ;23 with few uredinia, which was similar to the infection of the Thatcher line with Lr34. Cvs. Amazon, Aurora, HJ98, Ingot, Keystone, Marshall, Mercury, Era, and Roblin had infection type of $2^{+}$, which also was similar to the Thatcher line with Lr34. Cvs. Dandy and Ivan had infection types of $; 12^{-}$and $; 1$, respectively, to TDBJ.

The cultivars also were tested with MCDS, TNRJ, MBRJ, MBRK, or TDBJ for the second isolate in the adult plant tests. Forge, Hanna, McKenzie, Norm, and Norpro had infection types of $; 2^{-}$to $; 2$ to MCDS. Cvs. 2375, BacUp, Keystone, McVey, Glenlea, and Roblin had infection types of ;23, with few uredinia, to MCDS, which was similar to the infection type of the Thatcher line with Lr34. Alsen, Dandy, Gunner, Ivan, and Oxen had 0; to ; (fleck) infection types to isolate TNRJ. Amazon and Marshall had infection types of ;23 and $23^{+}$, respectively to TNRJ. Aurora and HJ98 had infection types of $; 1^{-}$and $; 2^{-}$, respectively, to isolate MBRJ. Cvs. Ember and Ingot had infection types of $; 2^{-}$and ; (fleck), respectively, to isolate MBRK.

Cvs. Dandy, Ivan, Knudson, McKenzie, and Norm were highly resistant, with leaf rust severity and response readings of 0 to $5 \mathrm{MR}$ in all three of the field tests in 2002 and 2003 (Table 5). Alsen also had good resistance, with severity and response of 5 MR to $10 \mathrm{MR}$ MS. Cv. Ingot was moderately susceptible in all three tests, with leaf rust severities and responses of 30 to 60 MS. The other cultivars all had an intermediate level of resistance, with severity and response readings between $5 \mathrm{MR}$ to $50 \mathrm{MR}$ MS at one or more of the three locations.

Thatcher was rated as $80 \mathrm{~S}$ at the three locations. The Thatcher lines with $\operatorname{Lrl}$, $L r 3, L r 10, L r 12$, and Lr14a, were highly susceptible, with severities and responses of 40 to $80 \mathrm{~S}$ at all three locations. The Thatcher lines with $L r 2 a$ and $L r 2 c$ were at $80 \mathrm{~S}$ in St. Paul in 2002, but were only 20 $S$ at St. Paul in 2003. The Thatcher lines with $L r 3 k a$ and $L r 11$ were $60 \mathrm{~S}$ and $70 \mathrm{~S}$, respectively, in 2002 , and were 10 to 20 MR and 20 MR MS, respectively, in St. Paul in 2003. The Thatcher lines with pairs of genes Lr13, Lr24; Lr21, Lr34; and $\operatorname{Lr} 13, \operatorname{Lr} 21$ had low severity and response ratings of 0 to $10 \mathrm{MR}$ at St. Paul in 2002 and 2003. The other Thatcher lines with combinations of seedling genes and either Lr13 or Lr34 had severities and responses of 10 to $70 \mathrm{MR}$ MS in both years at St. Paul.

Table 5. Leaf rust severity and resistance response of hard red spring wheat cultivars and Thatcher near-isogenic lines in field plots in St. Paul, MN and Fargo, ND in 2002 and 2003

\begin{tabular}{|c|c|c|c|c|}
\hline \multirow[b]{2}{*}{ Cultivar } & \multirow[b]{2}{*}{ Postulated $L r$ genes } & \multicolumn{2}{|c|}{2002} & \multirow{2}{*}{$\begin{array}{c}2003 \\
\text { St. Paul }\end{array}$} \\
\hline & & St. Paul & Fargo & \\
\hline 2375 & $\operatorname{Lr} 1^{\mathrm{b}}$ & $40 \mathrm{MR}$ MS & 5-10 MR MS & $30 \mathrm{MR}$ MS \\
\hline Alsen & $\operatorname{Lr} 2 a, \operatorname{Lr} 10$ & $10 \mathrm{MR}$ MS & $5 \mathrm{MR}$ & $10 \mathrm{MR} M S$ \\
\hline Amazon & Lr1, Lr10 & $20 \mathrm{MR}$ MS & $10-20 \mathrm{MR}$ & $40 \mathrm{MR}$ MS \\
\hline Aurora & Lr16 & 10-20 MR MS & 5 MR MS & $10 \mathrm{MR}$ MS \\
\hline BacUp & Lr1, Lr10 & 40 MR MS & $10 \mathrm{MS}$ & 30 MR MS \\
\hline Dandy & $\operatorname{Lr} 24$ & $5 \mathrm{R}$ & $5 \mathrm{MR}$ & 0 \\
\hline Ember & $\operatorname{Lr} 2 a, \operatorname{Lr} 16$ & 40-60 MR MS & $50 \mathrm{MS}$ & $20 \mathrm{MR}$ MS \\
\hline Forge & Lr2a, Lr16 & 40-50 MR MS & $30 \mathrm{MS}$ & $40 \mathrm{MR}$ MS \\
\hline Gunner & $\operatorname{Lr} 2 a^{\mathrm{b}}$ & 5-20 MR MS & $30-40 \mathrm{MS}$ & 20-30 MR MS \\
\hline Hanna & Lr16 & 30-50 MR MS & $20 \mathrm{MS}$ & $30 \mathrm{MR}$ MS \\
\hline HJ98 & $\operatorname{Lr} 10^{\mathrm{b}}$ & 20 MR MS & $10 \mathrm{MR}$ MS & 20 MR MS \\
\hline Ingot & Lr16 & $50-60 \mathrm{MS}$ & 30-40 MS & $50 \mathrm{MS}$ \\
\hline Ivan & Lr24 & 0 & 0 & $5 \mathrm{R}$ MR \\
\hline Keystone & Lr16 & 10-20 MR MS & $5 \mathrm{MR}$ MS & $30 \mathrm{MR}$ MS \\
\hline Knudson & Lr16 & $5 \mathrm{R}$ & 0 & 0 \\
\hline Marshall & $\operatorname{Lr} 2 a, \operatorname{Lr} 10^{\mathrm{b}}$ & 20 MR MS & $10 \mathrm{MR}$ & 30 MR MS \\
\hline McKenzie & $\operatorname{Lr} 21$ & $5 \mathrm{R}$ & $5 \mathrm{R}$ & 0 \\
\hline McVey & Lr16 & 5-10 MR & $5 \mathrm{MR}$ MS & $30 \mathrm{MR}$ MS \\
\hline Mercury & Lr16 & 5 R- 20 MR MS & 5-10 MR MS & 5 MR MS \\
\hline Norm & Lr16 & 0 & 0 & 0 \\
\hline Norpro & $\operatorname{Lr} 2 a, \operatorname{Lr} 16$ & 10-20 MR MS & 5 MR MS & 20 MR MS \\
\hline Oxen & $\operatorname{Lr} 1, \operatorname{Lr} 2 a, \operatorname{Lr} 10^{\mathrm{b}}$ & $20 \mathrm{MR}$ MS & $20 \mathrm{MS}$ & $30 \mathrm{MR}$ MS \\
\hline Parshall & $\operatorname{Lrl6}$ & 20-30 MR MS & 20-30 MR MS & $30-40 \mathrm{MS}$ \\
\hline Reeder & $\operatorname{Lr} 2 a, \operatorname{Lr} 16$ & 20-30 MS & 5-10 MS & $10-20 \mathrm{MS}$ \\
\hline Russ & $\operatorname{Lr} 2 a, \operatorname{Lr} 10^{\mathrm{b}}$ & 10-20 MR MS & 20-30 MS & 5-10 MR MS \\
\hline Verde & Lr16 & 10-20 MR MS & $5 \mathrm{R}$ & 5-20 MR \\
\hline Era & Lr10, Lr13, Lr34 & $\ldots$ & $5 \mathrm{MR}$ MS & $10 \mathrm{MR}$ MS \\
\hline Glenlea & Lr1, Lr34 & $\ldots$ & $20 \mathrm{MR}$ & $10-20 \mathrm{MR}$ \\
\hline Roblin & Lr1, Lr10, Lr13, Lr34 & $\ldots$ & $10 \mathrm{MR}$ & $50 \mathrm{MR}$ \\
\hline RL 6003 & Lr1 & $80 \mathrm{~S}$ & $\ldots$ & $80 \mathrm{~S}$ \\
\hline RL 6016 & $\operatorname{Lr} 2 a$ & $60 \mathrm{~S}$ & $\ldots$ & $20 \mathrm{~S}$ \\
\hline RL 6047 & $\operatorname{Lr} 2 c$ & $60 \mathrm{~S}$ & $\ldots$ & $20 \mathrm{~S}$ \\
\hline RL 6002 & Lr3 & $70 \mathrm{~S}$ & $\ldots$ & $50-70 \mathrm{~S}$ \\
\hline RL 6004 & $\operatorname{Lr} 10$ & $80 \mathrm{~S}$ & $\ldots$ & $50-80 \mathrm{~S}$ \\
\hline RL 6001 & $\operatorname{Lr} 12$ & $80 \mathrm{~S}$ & $70 \mathrm{~S}$ & $50 \mathrm{~S}$ \\
\hline RL 4031 & $\operatorname{Lr13}$ & $50 \mathrm{MR}$ MS & $50 \mathrm{~S}$ & $50 \mathrm{MR}$ MS \\
\hline RL 6013 & $\operatorname{Lr} 14 a$ & $80 \mathrm{~S}$ & $\ldots$ & $50-70 \mathrm{~S}$ \\
\hline RL 6005 & Lr16 & 30 MS S & $\ldots$ & 60 MS S \\
\hline RL 6043 & $\operatorname{Lr} 21$ & $10 \mathrm{MR}$ MS & $\ldots$ & $5 \mathrm{MR}$ \\
\hline RL 6044 & $\operatorname{Lr} 23$ & 20 MR MS & $\ldots$ & 20 MR MS \\
\hline RL 6064 & Lr24 & 10 MR MS & $\ldots$ & $10-20 \mathrm{~S}$ \\
\hline RL 6058 & Lr34 & 30-50 MR MS & $\ldots$ & 40-60 MR MS \\
\hline RL 6122 & Lrl, Lr13 & $20-40$ MR MS & $\ldots$ & $50 \mathrm{MR}$ MS \\
\hline RL 6108 & Lr1, Lr34 & 30-60 MR MS & $\ldots$ & 40-50 MR MS \\
\hline RL 6109 & $\operatorname{Lr} 2 a, L r 34$ & $50 \mathrm{MR}$ MS & $\ldots$ & 10-40 MR MS \\
\hline RL 6125 & Lr3, Lr13 & $50 \mathrm{MR}$ MS & $\ldots$ & 50 MR MS \\
\hline RL 6110 & Lr3, Lr34 & 40 MR MS & $\ldots$ & 50-70 MR MS \\
\hline RL 6112 & Lr10, Lr34 & $30 \mathrm{MR}$ MS & $\ldots$ & 50-70 MR MS \\
\hline RL 6114 & Lr13, Lr34 & 10-20 MR MS & $\ldots$ & 30-40 MR MS \\
\hline RL 6128 & Lr13, Lr16 & 50 MR MS & $\ldots$ & 30-40 MR MS \\
\hline RL 6115 & Lr16, Lr34 & 20 MR MS & $\ldots$ & 20-30 MR MS \\
\hline RL 6131 & Lr13, Lr21 & 10-20 MR & $\ldots$ & 0 \\
\hline RL 6118 & Lr21, Lr34 & $5 \mathrm{MR}$ & $\ldots$ & 0 \\
\hline RL 6132 & Lr13, Lr24 & $10 \mathrm{MR}$ & $\ldots$ & $5 \mathrm{R}$ \\
\hline Thatcher & $\ldots$ & $80 \mathrm{~S}$ & $80 \mathrm{~S}$ & $80 \mathrm{~S}$ \\
\hline
\end{tabular}

${ }^{a}$ Rust response: $0=$ no flecks or uredinia, $\mathrm{R}=$ small uredinia with necrosis, $\mathrm{MR}=$ mixture of small and large uredinia with necrosis, $\mathrm{MS}=$ moderate size uredinia with chlorosis, $\mathrm{S}=$ large uredinia, without necrosis or chlorosis; $\ldots=$ not tested.

b An additional gene is present, either $L r 3, \operatorname{Lr} 14 a$, or $\operatorname{Lr} 23$. 


\section{DISCUSSION}

Based on the seedling infection type data, Lr1, Lr2a, Lr10, Lr16, Lr21, and $L r 24$, were postulated to be present in the hard red spring wheat cultivars grown in Minnesota and the Dakotas. The high levels of field resistance of Dandy, Ivan, Knudson, and Norm likely was due to combinations of seedling resistance genes such as $L r 16$ or $L r 24$ with at least one adult plant resistance gene. The Thatcher line with Lrl6 had response and severity ratings of $30 \mathrm{MS}$ and $60 \mathrm{MS} \mathrm{S}$ in 2002 and 2003, respectively, in St. Paul. Virulence phenotype THBJ with virulence to Lr16 has been a common phenotype in Minnesota and the Dakotas since 2001 (14), yet Lr16 still conditions some degree of effective leaf rust resistance. Gene $L r 24$ is still highly effective because virulence to this gene is at a very low level in the P. triticina population in the upper Midwest (14). Gene Lrl6 has been shown to interact with Lr34 and Lr13 to condition lower seedling infection types and higher field resistance than either of the seedling or adult plant genes condition separately $(9,26)$.

Cv. Norm had a ;1 infection type to THBJ in the adult plant test, and had a $2^{+} 3$ infection type to this isolate in the seedling tests. Based on these infection types, Norm likely has at least one additional resistance gene. Results from a genetic study have indicated that Norm has Lrl, Lr10, Lrl6, Lr13, Lr23, and Lr34 (L. M. Oelke, unpublished data). $\mathrm{Cv}$. Alsen, postulated to have seedling genes $L r 2 a, L r 10$, and either Lr3, $L r 14 a$, or $L r 23$, also had good field resistance at all three field locations. Results from a genetic study indicate that Alsen has Lr2a, Lr10, Lr13, Lr23, and Lr34 (L. M Oelke, unpublished data). The seedling infection type data in this study indicated that Alsen was heterogeneous for an additional seedling resistance gene, which could be Lr16. McKenzie was postulated to have $L r 21$ based on pedigree and the low infection types to all the isolates used in this study. McKenzie must also have an adult plant gene because, in the field tests, it had lower rust severity and response compared with the Thatcher line with Lr21. The Thatcher line with Lr21 and Lr34 had very low leaf rust severity readings in both field tests.

Cvs. Aurora, Mercury, Ember, Forge, Keystone, McVey, Norpro, Parshall, Reeder, and Verde, which all were postulated to have Lr16, had an intermediate level of MR to MS field resistance. These lines also likely have some additional adult plant resistance genes. In the adult plant test, Aurora, Mercury, McVey, Keystone, and Reeder had infection types to isolate THBJ that were similar to the infection type of the Thatcher line with Lr34. Ember, Forge, Norpro, Parshall, and Verde had infection types to THBJ in the adult plant test that were lower than the Thatcher line with $L r 34$. This could be due to the inter- action of Lr34 with Lr16, or it also could be due to the presence of Lrl6 singly. Kolmer (10) found that isolates of $P$. triticina that had high infection types to the Thatcher line with Lrl6 in seedling tests often had lower infection types to adult plants of the same line. This makes it difficult to distinguish between the effect of Lr34 interacting with Lr16, or the presence of Lr16 or Lr34 singly, in gene postulation studies. Cultivars that have LrI6 and Lr34 often have lower seedling infection types to isolates virulent on the Thatcher line with Lr16. Ingot, also postulated to have Lr16, was moderately susceptible at all locations in the field test and most likely does not have an additional adult plant resistance gene.

Cvs. 2375, Amazon, BacUp, Gunner, HJ98, Marshall, Oxen, and Russ were postulated to have combinations of $\mathrm{Lrl}$, $L r 2 a$, and Lr10. The cultivars with only $L r 1, L r 2 a$, or $L r 10$ for seedling resistance genes also must have some effective adult plant resistance genes. Amazon, HJ98, and Marshall had infection type $23^{+}$to isolate THBJ in the adult plant tests, which indicated these cultivars probably have Lr34. Cvs. 2375, BacUp, and Oxen had lower infection types of ; 2 to $; 23$ to THBJ. These cultivars probably have Lr34 and may have an additional adult plant resistance gene. Cv. Russ had a 0; infection type to both THBJ and TNRJ in the adult plant tests. Russ must have an additional adult plant resistance gene. All of these cultivars also had intermediate leaf rust severities with MR to MS responses in the field plots at St. Paul. Roblin, with genes Lrl, LrlO, Lr13, and Lr34 (3), had an infection type of 23 to THBJ in the adult plant test, and was $10 \mathrm{MR}$ and $50 \mathrm{MR}$ in Fargo in 2002 and St. Paul in 2003, respectively. Glenlea, with genes $L r 1$ and $L r 34$, had a ;23 infection type to THBJ in the adult plant test, and a ;3 infection type to MCDS. Glenlea was 10 to $20 \mathrm{MR}$ in Fargo and St. Paul in 2002 and 2003, respectively. Dyck et al. (6) determined that Glenlea had Lr34 and an additional adult plant resistance gene.

Genes $L r 3, L r 14 a$, or $L r 23$ likely were present in some cultivars, but could not be differentiated with the isolates used in this study. Gene Lr14a originally was derived from the tetraploid Yaroslav emmer (12), which was used as an early stem rust-resistant parent in the hard red spring wheat breeding programs. Gene Lr23 originally was derived from the durum wheat Gaza (2) and also may be present in hard red spring wheat cultivars $(24,30)$. The older Minnesota cv. Lee was the source of $L r 23$ for the Thatcher line with this gene (18). The temperature sensitivity of Lr23 makes it difficult to consistently score infection types for wheat lines with this resistance gene. The Thatcher line with Lr23 had effective resistance in the field plot tests in St. Paul in 2002 and 2003. Gene Lr23 likely contributes some degree of effective resistance in the hard red spring wheat cultivars. Gene $L r 3$ originally was derived from winter wheat cultivars $(5,20)$ and is less likely to be present in hard red spring wheat. Nearly all of the $P$. triticina isolates in the United States are virulent to Lr3 and Lr14a (14); therefore, these two genes would not condition any effective leaf rust resistance in cultivars.

It is likely that the cultivars in this study also had other seedling resistance genes, because the limiting factors in any gene postulation study are the virulence combinations of the isolates. For example, only KFBJ was avirulent on $L r l$. KFBJ also was avirulent on Lr16, which made it impossible to distinguish lines that might have $L r l$ and $L r 16$. It also was not possible to clearly identify which cultivars had Lr34 based on the adult plant infection types and field resistance. The presence of seedling $L r$ genes, especially $L r 16$, confounded some of these results. Genetic analysis of segregating populations remains the best method to determine which seedling and adult plant $L r$ genes are present in wheat germplasm.

Adult plant resistance gene Lr34, which likely is present in many of these wheat cultivars, conditions an intermediate level of nonspecific resistance to leaf rust. Isolates of $P$. triticina with complete virulence to adult plants with $L r 34$ have not been described (14). However, most isolates are virulent to $\operatorname{Lr} 13$, which also is likely present in many of these cultivars. Gene Lr13 has been present in U.S. spring wheat cultivars since cv. Chris was released in the mid-1960s (25) and was highly effective for a number of years. Cv. Era (7), with Lr10, Lr13, and Lr34, has been used extensively as a parent. In recent years, $\operatorname{Lr} 13$ has lost effectiveness as virulent leaf rust isolates have increased.

This study confirms that the wheat cultivars with the best leaf rust resistance have combinations of effective seedling and adult plant resistance genes. Additional seedling resistance genes should be added to the spring wheat germplasm, because $L r 16, L r 21$, and $L r 24$ were the only seedling genes found in these cultivars that conditioned effective field resistance. Other adult resistance genes, such as Lr46 (28), a slow-rusting adult resistance gene, also should be utilized to enhance leaf rust resistance in the spring wheat cultivars. The genetically variable and dynamic nature of the $P$. triticina population in the United States requires that new leaf rust resistance genes be added to wheat germplasm on a regular basis in order to maintain effective levels of field resistance.

\section{LITERATURE CITED}

1. Browder, L. E. 1973. Probable genotype of some Triticum aestivum Agent derivatives for reaction to Puccinia recondita f. sp. tritici. Crop Sci. 13:203-206

2. Dyck, P. L. 1982. Genetic inhibition of expression of resistance gene $L r 23$ in wheat to Puc- 
cinia recondita. Can. J. Plant Sci. 62:219-220.

3. Dyck, P. L. 1993. Inheritance of leaf rust and stem rust resistance in 'Roblin' wheat. Genome 36:289-293.

4. Dyck, P. L., and Kerber, E. R. 1985. Resistance of the race-specific type. In: The Cereal Rusts, vol. 2. A. P. Roelfs and W. R. Bushnell, eds. Academic Press, Orlando, FL.

5. Dyck, P. L., and Samborski, D. J. 1968. Genetics of resistance to leaf rust in the common wheat varieties Webster, Loros, Brevit, Carina, Malakof and Centenario. Can. J. Genet. Cytol. 10:7-17.

6. Dyck, P. L., Samborski, D. J., and Martens, J. W. 1985. Inheritance of resistance to leaf rust and stem rust in the wheat cultivar Glenlea. Can. J. Plant Pathol. 7:351-354.

7. Ezzahiri, B., and Roelfs, A. P. 1989. Inheritance and expression of adult plant resistance to leaf rust in Era wheat. Plant Dis. 73:549551.

8. Flor, H. H. 1971. Current status of the genefor-gene concept. Annu. Rev. Phytopathol. 9:275-296.

9. German, S. E., and Kolmer, J. A. 1992. Effect of gene Lr34 in the enhancement of resistance to leaf rust of wheat. Theor. Appl. Genet. 84:97-105.

10. Kolmer, J. A. 1992. Enhanced leaf rust resistance in wheat conditioned by resistance gene pairs with Lr13. Euphytica 61:123-130.

11. Kolmer, J. A. 1996. Genetics of resistance to wheat leaf rust. Annu. Rev. Phytopathol. 34:435-455.

12. Kolmer, J. A., Dyck, P. L., and Roelfs, A. P. 1991. An appraisal of stem and leaf rust resis- tance in North American hard red spring wheats and the probability of multiple mutations in populations of cereal rust fungi. Phytopathology 81:237-239.

13. Kolmer, J. A., and Liu, J. Q. 2002. Inheritance of leaf rust resistance in the wheat cultivars AC Majestic, AC Splendor, and AC Karma. Can. J. Plant Pathol. 24:327-331.

14. Kolmer, J. A., Long, D. L., Kosman, E., and Hughes, M. E. 2003. Physiologic specialization of Puccinia triticina on wheat in the United States in 2001. Plant Dis. 87:859-866.

15. Liu, J. Q., and Kolmer, J. A. 1997. Inheritance of leaf rust resistance in wheat cultivars Grandin and CDC Teal. Plant Dis. 81:505-508.

16. Loegering, W. Q., McIntosh, R. A., and Burton, C. H. 1971. Computer analysis of disease data to derive hypothetical genotypes for reaction of host varieties to pathogens. Can. J. Genet. Cytol. 13:742-748.

17. Long, D. L., and Kolmer, J. A. 1989. A North American system of nomenclature for Puccinia recondita f. sp. tritici. Phytopathology 79:525-529.

18. McIntosh, R. A., Wellings, C. R., and Park, R. F. 1995. Wheat Rusts: an Atlas of Resistance Genes. CSIRO Australia, Kluwer Academic Publishers, Dordrecht, The Netherlands.

19. McVey, D. V. 1989. Verification of infectiontype data for identification of genes for resistance to leaf rust in some hard red spring wheat. Crop Sci. 29:304-307.

20. McVey, D. V., and Long, D. L. 1993. Genes for leaf rust resistance in hard red winter wheat cultivars and parental lines. Crop Sci. 33:13731381
21. Person, C. 1959. Gene-for-gene relationships in host:parasite systems. Can. J. Bot. 37:11011130.

22. Peterson, R. F., Campbell, A. B., and Hannah, A. E. 1948. A diagrammatic scale for estimating rust intensity on leaves and stems of cereals. Can. J. Res. Sect. C 26:496-500.

23. Rizvi, S. S. A., and Buchenau, G. W. 1994. Tentative identification and verification of genes for leaf rust resistance in wheat cultivars of South Dakota. Plant Dis. 78:674-679.

24. Rizvi, S. S. A., and Statler, G. D. 1982. Probable genotypes of hard red spring wheats for resistance to Puccinia recondita f. sp. tritici. Crop Sci. 22:1167-1170.

25. Samborski, D. J. 1985. Wheat leaf rust. In: The Cereal Rusts, vol. 2. A. P. Roelfs and W. R. Bushnell, eds. Academic Press, Orlando, FL.

26. Samborski, D. J., and Dyck, P. L. 1982. Enhancement of resistance to Puccinia recondita by interactions of resistance genes in wheat. Can. J. Plant Pathol. 4:152-156.

27. Singh, R. P. 1993. Resistance to leaf rust in 26 Mexican wheat cultivars. Crop Sci. 33:633 637.

28. Singh, R. P., Mujeebkazi, A., and HuertaEspino, J. 1998. Lr46-A gene conferring slow rusting resistance to leaf rust in wheat. Phytopathology 88:890-894.

29. Singh, R. P., and Rajaram, S. 1991. Resistance to Puccinia recondita f. sp. tritici in $50 \mathrm{Mexi}-$ can bread wheat cultivars. Crop Sci. 31:1472 1479

30. Statler, G. D. 1984. Probable genes for leaf rust resistance in several hard red spring wheats. Crop Sci. 24:883-886 